\title{
THE USE OF A BILE-AESCULIN MEDIUM AND OF MAXTED'S TECHNIQUE OF LANCEFIELD GROUPING IN THE IDENTIFICATION OF ENTEROCOCCI (GROUP $D$ STREPTOCOCCI)
}

\author{
BY \\ ALEXANDER SWAN \\ From the Department of Pathology, King's College Hospital Medical School, University \\ of London
}

(RECEIVED FOR PUBLICATION SEPTEMBER 5, 1953)

The name enterococcus, originally given by Thiercelin (1899) to a Gram-positive coccus of faecal origin growing in pairs and short chains, has been widely used for a group of morphologically similar streptococci found in the gut of man and other mammals, in dairy products, and in soil. The limits of this group, formerly rather vague, were satisfactorily defined with the application to it of Lancefield grouping methods by Sherman and his collaborators (Sherman, 1937; Sherman, Mauer, and Stark, 1937 ; Sherman, Stark, and Mauer, 1937 ; Sherman, Stark, and Yawger, 1937), and later by Shattock and Mattick (1943) and Shattock (1945 and 1949b). From this work it is apparent that the great majority, if not all, enterococci belong to Lancefield Group $D$, and that in fact this serological property should be taken as the basis of their classification. The group will then include the following species: Strep. faecalis, with its varieties, zymogenes, and liquefaciens, Strep. durans, and Strep. bovis.

The degree of variation in the biological properties of Group $D$ streptococci is well shown in Table I reproduced from Shattock (1949b ; see also Nyman, 1949).

Table I covers the majority of important biological properties of the group, except bile tolerance, or the ability to grow in the presence of bile in concentrations up to $40 \%$ (Weissenbach, 1918), which is usually regarded as common to all species of enterococci, and aesculin hydrolysis.

Attention was drawn to the value of aesculin hydrolysis in the identification of enterococci by Rochaix (1924), and the use of aesculin in bile media was regarded as the best single differential test by Meyer and Schönfeld (1926), who found that 61 of their 62 strains of enterococci hydrolysed aesculin, as compared with only six among
82 strains of Strep. viridans. Weatherall and $\overrightarrow{7}$ Dible (1929), who obtained similar results, 60 of their 61 bile-tolerant, heat-resistant, mannitolfermenting diplococci hydrolysing aesculin, con- $\vec{c}$ sidered, however, that the hydrolysis of aesculin + in a bile medium was "very little more than an indicator" of bile tolerance. This conclusion was? probably responsible for the fact that the test has $\frac{\partial}{0}$ been little used. The work of Williams and Hircho (1950) suggests, however, that aesculin hydrolysis $\stackrel{2}{\AA}$ has an independent value in the classification of $\underset{\vec{B}}{\stackrel{2}{*}}$ bile-tolerant cocci, as only $83.6 \%$ of their 140 윽 strains of bile-tolerant streptococci hydrolysed $\vec{J}$ aesculin.

The present paper records an attempt to find a simple, rapid and accurate single procedure foro the recognition of enterococci as a group, minorsubdivisions of which are of little importance in. the routine diagnostic work of a medical labora-o tory. Results of Lancefie!d $D$ grouping were com -2 pared with those of tests for bile tolerance and은 aesculin hydrolysis, as well as heat resistance, on $>$ a number of freshly isolated and stock strains of streptococci.

\section{Source of Material}

One hundred and forty-two strains of streptococci and eight strains of micrococci were iso을 lated from human material in the laboratory ofo a general hospital. The sources of these strainsD are shown in Table II.

In addition, nine stock strains of Strep. bovis three isolated from human intestine and six from the rumen of the cow, and 12 strains of Strep? durans were examined. Of the latter, two wer@ recovered from the human intestines, the reg mainder being mostly obtained from milk and dairy products. 
TABLE I

DIFFERENTIATION OF SPECIES WITHIN GROUP $D$ REPRODUCED FROM SHATTOCK (1949a)

\begin{tabular}{|c|c|c|c|c|c|c|c|c|c|}
\hline \multirow[b]{2}{*}{ Species } & \multirow[b]{2}{*}{ Haemolysis } & \multirow{2}{*}{$\begin{array}{c}\text { Gelatin } \\
\text { Liquefaction }\end{array}$} & \multirow{2}{*}{$\begin{array}{l}\text { Strong } \\
\text { Reduction } \\
\text { of Litmus } \\
\text { Milk }\end{array}$} & \multirow[b]{2}{*}{ Mannitol } & \multirow[b]{2}{*}{ Sucrose } & \multirow[b]{2}{*}{ Raffinose } & \multirow{2}{*}{$\begin{array}{c}\text { Survival } \\
\text { at } 60^{\circ} \mathrm{C} \text {. } \\
\text { for } \\
30 \mathrm{~min} .\end{array}$} & \multicolumn{2}{|c|}{ Growth } \\
\hline & & & & & & & & $45^{\circ} \mathrm{C}$. & $\underset{p H=9.6}{\mathbf{A t}}$ \\
\hline $\begin{array}{l}\text { Strep. faecalis } \\
\text { Strep. faecalis, vari- } \\
\text { ety zymogenes . } \\
\text { Strep. faecalis, vari- } \\
\text { ety liquefaciens. } \\
\begin{array}{l}\text { Strep. durans } \\
\text { " bovis }\end{array}\end{array}$ & $\begin{array}{l}- \\
+ \\
\overline{ \pm}\end{array}$ & $\begin{array}{l}- \\
\pm \\
+ \\
-\end{array}$ & $\begin{array}{l}+ \\
\pm \\
\pm \\
\pm\end{array}$ & $\begin{array}{l}+ \\
+ \\
+ \\
\pm\end{array}$ & $\begin{array}{l} \pm \\
+ \\
+ \\
+\end{array}$ & $\begin{array}{l}- \\
- \\
\overline{+}\end{array}$ & $\begin{array}{l}+ \\
+ \\
+ \\
+\end{array}$ & $\begin{array}{l}+ \\
+ \\
+ \\
\pm \\
+\end{array}$ & $\begin{array}{l}+ \\
+ \\
+ \\
\pm\end{array}$ \\
\hline
\end{tabular}

$\pm=$ Varies from strain to strain.

TABLE II

SOURCES OF STRAINS ISOLATED IN THE HOSPITAL LABORATORY

\begin{tabular}{|c|c|c|c|c|}
\hline Sources & $\begin{array}{l}\text { Presumptive } \\
\text { Enterococci }\end{array}$ & $\begin{array}{c}\text { Presumptive } \\
\text { Strep. } \\
\text { viridans }\end{array}$ & Micrococci & $\begin{array}{c}\text { Total } \\
\begin{array}{c}\text { Numbers of } \\
\text { Strains }\end{array}\end{array}$ \\
\hline 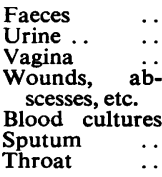 & $\begin{array}{r}65 \\
38 \\
10 \\
\\
5 \\
2 \\
1 \\
0\end{array}$ & $\begin{array}{r}1 \\
0 \\
0 \\
0 \\
0 \\
0 \\
0 \\
20\end{array}$ & $\begin{array}{l}8 \\
0 \\
0 \\
0 \\
0 \\
0 \\
0 \\
0\end{array}$ & $\begin{array}{r}74 \\
38 \\
10 \\
\\
5 \\
2 \\
2 \\
1 \\
20\end{array}$ \\
\hline Total & 121 & 21 & 8 & 150 \\
\hline
\end{tabular}

\section{Methods of Isolation}

One hundred and thirty strains of Gram-positive cocci were selected on the basis of their colonial morphology on McConkey medium. They appeared as small, discrete colonies, most of which were lactose fermenting. Microscopical examination of broth cultures showed eight of these strains to be micrococci and one to be a long-chained streptococcus. The remaining 121 strains, which grew in pairs or short chains, have, for convenience, been referred to throughout this paper as "presumptive enterococci."

To contrast with these, 20 strains of alphahaemolytic streptococci were isolated from the throats of healthy persons. These strains have been classed with the alpha-haemolytic longchained streptococcus of faecal origin as "presumptive Strep. viridans."

\section{Methods of Testing}

All strains were examined by the following tests: Lancefield grouping, heat-resistance, bile-tolerance, aesculin-hydrolysis.

Sixty-eight strains were also tested for fermentation of mannitol and the ability to grow in nutrient broth containing $6.5 \% \mathrm{NaCl}$, on blood-agar containing $0.06 \%$ potassium tellurite, and in milk containing $0.1 \%$ methylene blue, with the decolorization of the dye.
Lancefield Grouping. - (1) The hot-HCl-hydrolysis technique of Lancefield (1933) was employed throughout, using the sediment from $10 \mathrm{ml}$. of overnight glucose-broth cultures.

(2) All freshly isolated strains (150) were moreover grouped by a modification of the enzyme method of Maxted (1948). The enzyme was prepared by freezing and thawing an agar culture of Streptomyces albus. The fluid collected after thawing, which contains the enzyme, was stored without preservative at a temperature below $5^{\circ} \mathrm{C}$; ; under these conditions its activity was retained for some months. Seitz filtration and $p \mathrm{H}$ adjustment were omitted on Mr. W. R. Maxted's advice. The streptococci were grown in 10 $\mathrm{ml}$. of glucose broth, or beef-digest broth, for 18 hours. After centrifuging, the supernatant fluid was discarded, and the deposit placed for two minutes in boiling water. After cooling, $0.5 \mathrm{ml}$. of the proteolytic extract was added and the mixture incubated at $50^{\circ}$ C. overnight. As previously noted by Maxted (1948), Group $D$ streptococci were found rather resistant to the action of the enzyme, and even after this prolonged incubation the lysis was usually incomplete, making recentrifugation necessary. Satisfactory bacterial extracts were also obtained from enzymetreated saline suspensions of growth on blood-agar plates.

Streptococcal extracts prepared by both Lancefield's and Maxted's methods were tested in the same way by layering on to grouping serum (obtained from Messrs. Burroughs Wellcome, Ltd.) in glass tubes of $1 \mathrm{~mm}$. internal diameter. The results were read during the following 30 minutes.

Heat-resistance Test.-Approximately $1 \mathrm{ml}$. of an 18 to 24 hours' broth culture was placed in a $60^{\circ} \mathrm{C}$. water-bath ; a loopful was removed for subculture on blood-agar after 15, 30, 45, and 60 minutes. Strains surviving this temperature for 30 minutes were termed heat-resistant (Orla-Jensen, 1919 ; Dible, 1921).

Bile-tolerance Test.-Heavy inocula were made on segments of a nutrient-agar plate containing $5 \%$ horse serum, $0.1 \%$ aesculin, $0.05 \%$ ferric citrate, and sufficient "difco" dehydrated ox-gall powder to give a final concentration corresponding to $40 \%$ bile (Williams and Hirch, 1950). The plates were examined for growth after 24 hours' incubation. 
Hydrolysis of Aesculin.-This property was tested on the previously described bile-aesculin plate. Strains which hydrolysed aesculin produced a black colour in and immediately around the colonies. Bile-tolerant organisms which did not hydrolyse aesculin gave rise to whitish colonies. The plates were incubated for 24 hours; growth for a longer period was found not only unnecessary but also undesirable as it was liable to obscure the results, when as many as 12 strains were cultured on one plate. As Weatherall and Dible (1929) have pointed out, this is not truly a test of the capacity of an organism to hydrolyse aesculin, since strains which are not bile-tolerant do not grow on this medium and are, therefore, not tested.

\section{Results} IV.

The results are summarized in Tables III and

Of the 121 "presumptive enterococci," 117 belonged to Lancefield Group $D$. All these Group $D$ strains were heat-resistant, bile-tolerant, and all hydrolysed aesculin. Of the four strains which did not react with Group $D$ serum, two were heat-resistant but intolerant to bile, and two were neither heat-resistant nor bile-tolerant. These four strains were alpha-haemolytic.

None of the 21 strains of "presumptive Strep. viridans" reacted with Group $D$ serum and 19

TABLE III

RESULTS OF TESTS ON STRAINS OF ENTEROCOCCI

\begin{tabular}{|c|c|c|c|c|c|}
\hline $\begin{array}{l}\text { Total No. of } \\
\text { Strains Tested }\end{array}$ & $\begin{array}{c}\text { No. of } \\
\text { Strains } \\
\text { with } \\
\text { Common } \\
\begin{array}{c}\text { Proper- } \\
\text { ties }\end{array}\end{array}$ & $\begin{array}{l}\text { Lance- } \\
\text { field } \\
\text { Group } \\
\quad D\end{array}$ & $\begin{array}{l}\text { Heat } \\
\text { Resis- } \\
\text { tance }\end{array}$ & $\begin{array}{l}\text { Bile } \\
\text { Toler- } \\
\text { ance }\end{array}$ & $\begin{array}{l}\text { Aesculin } \\
\text { Hydro- } \\
\text { lysis }\end{array}$ \\
\hline $\begin{array}{l}\text { Presumptive entero- } \\
\text { cocci } 121\end{array}$ & $\begin{array}{r}117 \\
2 \\
2\end{array}$ & $\begin{array}{l} \pm \\
-\end{array}$ & $\begin{array}{l}+ \\
+ \\
-\end{array}$ & \pm & $\frac{ \pm}{-}$ \\
\hline Micrococci 8 & $\begin{array}{l}6 \\
2\end{array}$ & $\overline{-}$ & $\overline{-}$ & \pm & $\overline{-}$ \\
\hline $\begin{array}{l}\text { Presumptive } \\
\text { viridans } 21\end{array}$ & $\begin{array}{r}2 \\
19\end{array}$ & - & $\overline{-}$ & \pm & $\overline{-}$ \\
\hline Strep. bovis 9 & $\begin{array}{l}4 \\
5\end{array}$ & $\begin{array}{l}+ \\
+\end{array}$ & \pm & $\begin{array}{l}+ \\
+\end{array}$ & $\begin{array}{l}+ \\
+\end{array}$ \\
\hline Strep. durans 12 & 12 & + & + & + & + \\
\hline
\end{tabular}

TABLE IV

RESULTS OF ADDITIONAL TESTS ON 68 STRAINS OF ENTEROCOCCI

\begin{tabular}{|c|c|c|c|c|c|}
\hline & & $\begin{array}{l}\text { Growth } \\
\text { in } \\
\text { Medium } \\
\text { Contain- } \\
\text { ing 6.5\% } \\
\mathrm{NaCl}\end{array}$ & $\begin{array}{l}\text { Fermen- } \\
\text { tation of } \\
\text { Mannitol }\end{array}$ & $\begin{array}{c}\text { Growth } \\
\text { on Plate } \\
\text { Containing } \\
\text { 0.06\% } \\
\text { Pot. } \\
\text { Tellurite }\end{array}$ & $\begin{array}{c}\text { Growth in } \\
\text { Medium } \\
\text { Containing } \\
0.1 \% \\
\text { Methylene } \\
\text { Blue }\end{array}$ \\
\hline \multirow{2}{*}{$\begin{array}{l}\text { Numbers and } \\
\text { percentage } \\
\text { of strains }\end{array}$} & $\begin{array}{c}\text { Posi- } \\
\text { tive }\end{array}$ & $66(97 \%)$ & $67(98.5 \%$ & $64(94 \%)$ & $63(93 \%)$ \\
\hline & $\begin{array}{l}\text { Nega- } \\
\text { tive }\end{array}$ & 2 & 1 & 4 & 5 \\
\hline
\end{tabular}

of them were neither heat-resistant nor bile-을 tolerant ; two strains grew on bile-aesculin plates $\vec{F}$ without hydrolysing aesculin, but neither was $\stackrel{?}{?}$ heat-resistant.

None of eight strains of micrococci was heat $-\frac{\overline{ }}{\bar{n}}$. resistant and none hydrolysed aesculin, but $\operatorname{six} \frac{\rho}{\widehat{\Phi}}$ were bile-tolerant.

All Strep. bovis and Strep. durans strains were bile-tolerant and hydrolysed aesculin, their extracts $\overrightarrow{-}$ reacted with Group $D$ serum without concentra- tion. All strains of Strep. durans were, more- $\vec{\omega}$ over, heat-resistant, but only four out of the nine? strains of Strep. bovis survived $60^{\circ} \mathrm{C}$. for $300^{\circ}$ minutes.

Table IV shows the results of the subsidiary four tests, mannitol fermentation and growth in media containing $6.5 \% \mathrm{NaCl}$, or $0.06 \%$ potassium응 tellurite, and in milk containing $0.1 \%$ methylene blue, performed on 68 of the above 117 Group $D, 3$ heat-resistant, bile-tolerant, aesculin hydrolysing strains. Only $60(88.3 \%)$ strains gave positive $\vec{c}$ results with all four tests.

All cocci (150 strains), with the exception of stock strains of Strep. bovis and Strep. durans, 0 were grouped by both Maxted's and Lancefield's methods. Both techniques gave identical precipi-o tation results with Group $D$ sera in all cases excepto one ; this strain gave a positive Group $D$ reaction $\cong$ on acid extraction but consistently negative results $\overrightarrow{0}$ when extracted by Maxted's method.

\section{Discussion}

All 138 Group $D$ strains, in this survey, ando none outside this group were found to possess:the property of aesculin hydrolysis. Bile toler ance, although equally constant within the group, $\delta$ was shared by some (six out of 33) strains out- $₹$ side it, and is therefore less specific for entero-o cocci. Heat resistance is evidently neither a constant nor exclusive character of Group $D$ strepto-을. cocci, for five out of nine strains of Strep. bovis failed to survive $60^{\circ} \mathrm{C}$. for 30 minutes, and on the other hand two of the 25 strains of Strep. viridans 0 (alpha-haemolytic streptococci not belonging to N Group $D$ ) proved to be heat-resistant.

The behaviour of two strains of alpha-haemo lytic, non-Group- $D$ streptococci and of six strains $\frac{-}{\varnothing}$ of micrococci, which grew on the bile aesculin? plate without hydrolysing aesculin, together with 0 the previously quoted figures from Williams andô

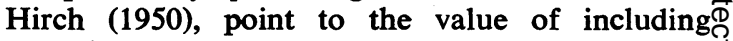
aesculin in a bile medium.

The bile-aesculin plate, therefore, appears to be a simple reliable means for the recognition of enterococci. It is much simpler and cheaper than 
Lancefield grouping, since as many as 12 strains can be inoculated on one plate.

The following procedure has been adopted in the routine work of this laboratory for the presumptive identification of enterococci. The Grampositive cocci are subcultured $(a)$ in $10 \mathrm{ml}$. of glucose broth and $(b)$ on a bile-aesculin plate. The next day the morphology of the growth in glucose broth is examined in a hanging drop. Strains growing in pairs and/or short chains and hydrolysing aesculin are classified as enterococci. The glucose broth culture is used only for the grouping of those strains which fail to hydrolyse aesculin.

It must be stressed that in this preliminary survey very small numbers of streptococci other than those of Group $D$ have been examined. Thus, whereas the property of aesculin hydrolysis in a bile-containing medium has been satisfactorily demonstrated among enterococci, its specificity for the group remains to be proved.

\section{Summary and Conclusions}

In an attempt to select a single reliable and simple method for the identification of enterococci (Group $D$ streptococci) the following principal tests were employed: Lancefield grouping, heatresistance, bile-tolerance, and aesculin hydrolysis. One hundred and seventeen Lancefield Group $D$ strains were found to be heat-resistant, bile-tolerant, and aesculin-hydrolysing. Of 25 alpha-haemolytic streptococci, not of Group $D$, none hydrolysed aesculin, but two were heat-resistant and two were bile-tolerant. From the very high correlation between Lancefield grouping and hydrolysis of aesculin on a bile-containing medium it has been concluded that the latter is a valid test for the recognition of enterococci, having the advantage of simplicity over the former.

Extracts for Lancefield grouping were prepared by two methods: (1) the hot- $\mathrm{HCl}$ technique of Lancefield and (2) the enzymic method of Maxted. Both methods gave equally good results.

I am greatly indebted to Dr. A. C. Cunliffe for his unstinted help and advice without which this work would have been impossible. I wish also to thank Mr. K. Tippett for general technical assistance, Mr. W. R. Maxted for advice in regard to his method of grouping and for supplying us with his strain of Streptomyces albus, Miss M. E. Sharp for the 21 strains of Strep. bovis and Strep. durans, and Miss P. M. F. Shattock for the permission to reproduce her Table of variability of properties within Group $D$ streptococci (our Table I).

\section{REFERENCES}

Dible, J. H. (1921). J. Path. Bact., 24, 3.

Lancefield, R. C. (1933). J. exp. Med., 57, 571.

Maxted, W. R. (1948). Lancet, 2, 255.

Meyer, K., and Schönfeld, H. (1926). Centralb. Bact., Abt. I, 99, 402.

Nyman, O. H. (1949). Acta path. Microbiol. scand., Suppl. 83, 1.

Orla-Jensen, S. (1919). The Lactic Acid Bacteria. Høst, Copenhagen.

Rochaix, A. (1924). C.R. Soc. Biol., Paris, 90, 771.

Shattock, P. M. F. (1945). Proc. Soc. agric. Bact., 1944, p. 69.

- (1949a). Report XIIth International Dairy Congress, Stockholm, Vol. 2, p. 598. Hæggstrøms, Stockholm.

- (1949b). J. gen. Microbiol., 3, 80.

and Mattick, A. T. R. (1943). J. Hyg. Camb., 43, 173.

Sherman, J. M. (1937). Bact. Rev., 1, 3.

Mauer, J. C., and Stark, Pauline (1937). J. Bact., 33, 275.

Stark, Pauline, and Mauer, J. C. (1937). Ibid., 33, 483.

- and Yawger, E. S. (1937). Ibid., 33, 25.

Thiercelin, E. (1899). C. R. Soc. Biol., Paris, 51, 269, 551.

Weatherall, C., and Dible, J. H. (1929). J. Path. Bact., 32, 413.

Weissenbach, R. J. (1918). C.R. Soc. Biol., Paris, 81, 559.

Williams, R. E. O., and Hirch, A. (1950). J. Hyg., Lond., 48, 504. 